\title{
EXPERIMENTAL INVESTIGATION OF SEISMIC PERFORMANCE OF BUILDING FRAME CONSIDERING SOIL STRUCTURE INTERACTION (SSI)
}

\author{
M. G. Kalyanshetti ${ }^{1}$, A.N.Wale ${ }^{2}$ \\ ${ }^{1}$ Civil Engineering Department, Walchand Institute of Technology, Solapur, Solapur University, India \\ ${ }^{2}$ Civil Engineering Department, Walchand Institute of Technology, Solapur, Solapur University, India
}

\begin{abstract}
In recent decades, SSI has been given much attention in both research and practice. The two reasons are its important effect on the response of buildings in earthquakes and second is its complexity. Present experimental study aims to evaluate the seismic performance of building frames under the fixed base conditions and flexible base conditions, on scale-down experimental steel model prepared using similitude laws. Three prototype RC building frames $G+3, G+5$ and $G+7$ are considered. The building frames considered are square in plan with single bay in both directions. The time history test (El-Centro) is conducted to know the acceleration of the test model. The acceleration $v / s$ time, velocity $v / s$ time and displacement $v \backslash s$ time plots are obtained for all the accelerometers. Study reveals that SSI effect is structure specific and input motion specific. Therefore during Earthquake depending upon frequency content of motion certain classes of buildings are subjected to damage
\end{abstract}

Keywords: Soil Structure Interaction, Fixed Base, Flexible Base, Time History Etc. $* * *$

\section{INTRODUCTION}

During theoretical analysis, certain set of assumptions regarding idealization of the material; boundary conditions etc. are required to be made to simplify the analysis to simulate the field conditions. However, these are not always true representation of what is happening in practice or field. It is observed that well engineered structures are also subjected to distress during earthquake. This happens due to the limitations in the analysis due to certain simplified assumptions. Therefore, in order to investigate the realistic behavior and to identify the various causes of distress in the structure, experimental study needs to be carried out which always gives a valuable insight with respect to limitations of various assumptions made while carrying out theoretical analysis of structures and the physical behavior of the structure.

Present experimental study aims to evaluate the seismic performance of building frames under the fixed base conditions and flexible base conditions, on scale-down experimental steel model prepared using similitude laws. The theory of similitude includes a consideration of condition under which the behavior of two separate entities or systems (model and prototype) will be nearly similar. Similitude is a tool to establish the sufficient and necessary condition of similarity between models and prototype.

\subsection{Scaled-Down Model}

Generally, a structural model is any structural element or assembly of structural elements built to a reduced scale with respect to prototype structures for testing, using laws of similitude. The results of the prototype structure are obtained by extrapolating the results of scaled down model using the similitude laws. Thus the performance of prototype structure can be predicted by carrying out the study on scaled down model.

\subsection{Prototype RC Building Frame Considered for} the Analysis

For the present study three building frames are considered that are $\mathrm{G}+3, \mathrm{G}+5$ and $\mathrm{G}+7$. Details of the building frames are given below, 
Table -1: Properties of building frames

\begin{tabular}{|c|c|c|c|c|}
\hline Sr. No & Contents & Description & & \\
\hline 1 & Structure & OMRF & OMRF & OMRF \\
\hline 2 & No. of stories & $\mathrm{G}+3$ & $\mathrm{G}+5$ & $\mathrm{G}+7$ \\
\hline 3 & Storey Height & $3.5 \mathrm{~m}$ & $3.5 \mathrm{~m}$ & $3.5 \mathrm{~m}$ \\
\hline 4 & $\begin{array}{ll}\text { Grade } & \text { of } \\
\text { Concrete } & \end{array}$ & M 25 & M 25 & M 25 \\
\hline 5 & Grade of Steel & $\mathrm{Fe} 415$ & $\mathrm{Fe} 415$ & $\mathrm{Fe} 415$ \\
\hline 6 & Bay width & $4 \mathrm{~m}$. & $4 \mathrm{~m}$. & $4 \mathrm{~m}$. \\
\hline 7 & Slab thickness & $0.15 \mathrm{~m}$ & $0.15 \mathrm{~m}$ & $0.15 \mathrm{~m}$ \\
\hline 8 & Size of Column & $\begin{array}{l}0.45 \mathrm{~m} \\
0.3 \mathrm{~m}\end{array}$ & $\begin{array}{l}0.40 \mathrm{~m} \\
0.25 \mathrm{~m} \\
0.45 \mathrm{~m} \\
0.45 \mathrm{~m}\end{array}$ & $\begin{array}{l}0.45 \mathrm{~m} \\
0.3 \mathrm{~m} \\
0.55 \mathrm{~m} \\
0.50 \mathrm{~m}\end{array}$ \\
\hline 9 & Size of Beam & $\begin{array}{l}0.4 \mathrm{~m} \\
0.23 \mathrm{~m}\end{array}$ & $\begin{array}{ll}0.4 \mathrm{~m} & \mathrm{x} \\
0.23 \mathrm{~m} & \end{array}$ & $\begin{array}{l}0.4 \mathrm{~m} \\
0.23 \mathrm{~m}\end{array}$ \\
\hline 10 & Floor finish & $0.6 \mathrm{KN} / \mathrm{m}^{2}$ & $0.6 \mathrm{KN} / \mathrm{m}^{2}$ & $0.6 \mathrm{KN} / \mathrm{m}^{2}$ \\
\hline 11 & Live load & $4 \mathrm{KN} / \mathrm{m}^{2}$ & $4 \mathrm{KN} / \mathrm{m}^{2}$ & $4 \mathrm{KN} / \mathrm{m}^{2}$ \\
\hline 12 & Seismic Zone & III & III & III \\
\hline
\end{tabular}

\subsubsection{Scale Factor}

Due to size limitation of shake table, the plan dimension of model is set as $0.32 \mathrm{~m}$. Thus, the $\mathrm{C} / \mathrm{C}$ distance between two columns is set as $0.32 \mathrm{~m}$ leading to a linear scale factor, of $4.0 / 0.32=12.5$. Therefore, Scale Factor $(\mathrm{SL})=12.5$

Employing geometric scaling factor of 1:12.5 as explained above height, length, and width of the structural model are determined to be, $1.120 \mathrm{~m}, 0.32 \mathrm{~m}$ and $0.32 \mathrm{~m}$, respectively. The scaling relationship between natural frequency of the model $(\mathrm{fm})$ and natural frequency of the prototype $(f p)$ is:

$$
\begin{aligned}
\mathrm{fm} / \mathrm{fp} & =\mathrm{S}_{\mathrm{L}}^{1 / 2} \\
& =3.54
\end{aligned}
$$

frequency of the prototype structure is $\mathrm{fp}=1.4792 \mathrm{~Hz}$. The required frequency of the model $(\mathrm{fm})$ is

$$
\begin{aligned}
& =1.4792 \times 3.54 \\
& =5.24 \mathrm{~Hz} .
\end{aligned}
$$

The density of the model ( $\rho m)$ should be equal to the density of the prototype $(\rho p)$.

Density of the prototype structure ( $\rho p)$ is determined as follows:

$$
\begin{aligned}
\rho p & =\text { mass of prototype/volume of prototype } \\
& =59140 /(14 \times 4 \times 4) \\
& =264.01 \mathrm{Kg} / \mathrm{m}^{3}
\end{aligned}
$$

Therefore the mass of the structural model (Mm) is estimated as:

$$
\begin{aligned}
\mathrm{Mm} & =\rho \mathrm{m} \times \mathrm{Vm}=264.01 \times(1.12 \times 0.32 \times 0.32) \\
& =30.27 \mathrm{Kg}
\end{aligned}
$$

The dimensions of column and slab of scale down steel model is derived in such a way that the weight of model nearly equals to $30.27 \mathrm{Kg}$ as required by simulated laws. Considering all above the details of $\mathrm{G}+3$ scale down steel model is worked out. Similar calculations were done for $\mathrm{G}+5$ and $\mathrm{G}+7$ steel models and the details of all scale down models are presented in Table 2.

Table 2: Geometric and material properties of scale down model

\begin{tabular}{|l|l|l|l|l|}
\hline Sr. No & Contents & Description & G+7 \\
\hline 1 & No. of stories & G+3 & G+5 & $280 \mathrm{~mm}$ \\
\hline 2 & Storey Height & $280 \mathrm{~mm}$ & $280 \mathrm{~mm}$ & Fe 250 \\
\hline 3 & Grade of Steel & Fe250 & Fe250 & $320 \mathrm{~mm}$ \\
\hline 4 & Bay width & $320 \mathrm{~mm}$ & $320 \mathrm{~mm}$. & $3 \mathrm{~mm}$ \\
\hline 5 & Slab thickness & $4 \mathrm{~mm}$ & $3 \mathrm{~mm}$ & $12 \mathrm{~mm} \mathrm{X} 12 \mathrm{~mm}$ \\
\hline 6 & Size of Column & $10 \mathrm{~mm}$ X $10 \mathrm{~mm}$ & $12 \mathrm{~mm} \mathrm{X} \mathrm{12mm}$ & $12 \mathrm{~mm} \mathrm{X} 12 \mathrm{~mm}$ \\
\hline 7 & Size of Plinth Beam & $10 \mathrm{~mm} \mathrm{X} \mathrm{10mm}$ & $12 \mathrm{~mm} \mathrm{X} \mathrm{12mm}$ & \\
\hline
\end{tabular}




\section{EXPERIMENTAL SETUP ON SHAKE TABLE}

An experimental study is carried out in order to validate the theoretical soil-structure interaction response. Two base conditions i.e. "Fixed-base" and "Flexible-base" are taken into account for the SSI evaluation process. The laboratory set up is developed for both fixed base condition and flexible base condition.

\subsection{Fixed Base Condition}

The fixed-base response of the scale down steel model is investigated by securing the foundation directly to the platform of the Shake Table. There are 4 numbers of accelerometers used to acquire the data. Accelerometer no. 1 is at bottom of Shake Table (Actuator), no. 2 and 3 are at slab level and accelerometer no. 4 is at roof level of scale down model. The experimental setup and placements of accelerometers are shown in Figure 1.

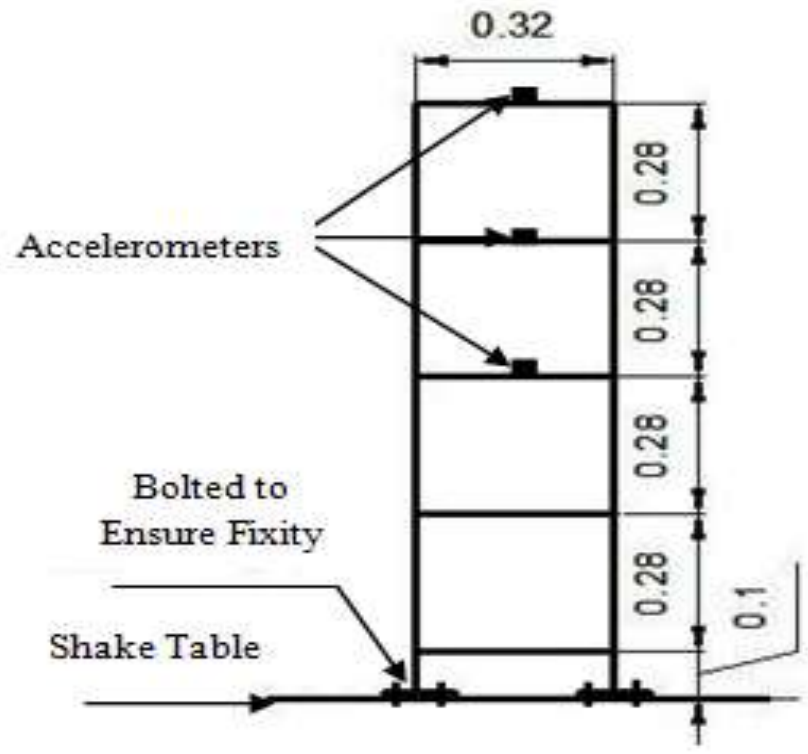

Fig -1: Details of Scale down Steel Model

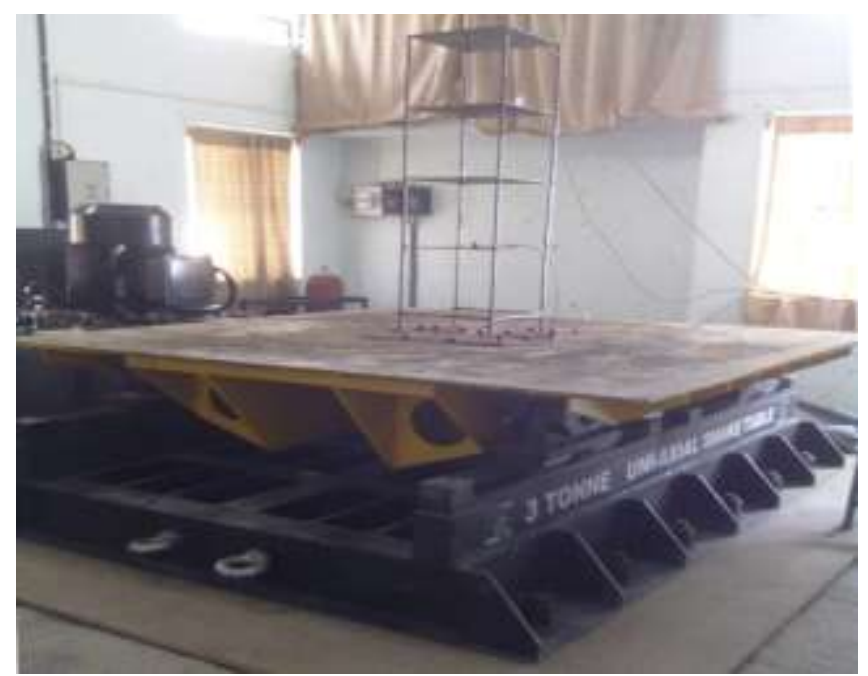

Fig-2: Model Fixed On Shake Table

\subsection{Flexible Base Condition}

To simulate soil structure interaction condition in the laboratory a container made of steel plates is used as shown in Figure 3. This container is used to hold the soil mass beneath the foundation. The container is mounted on shake table.

The finite soil mass is considered based on convergence study, with boundary far beyond a region where structural loading has no effect. This is assumed to be at a lateral offset of two times width of the building on all four sides and depth equal to 3 times the width of building. As per this guideline soil block of $1.6 \times 1.6 \mathrm{~m}$ in plan is required. However, considering limitation of Shake Table, container of size $1.5 \times 1.5 \times 0.7 \mathrm{~m}$ is used.

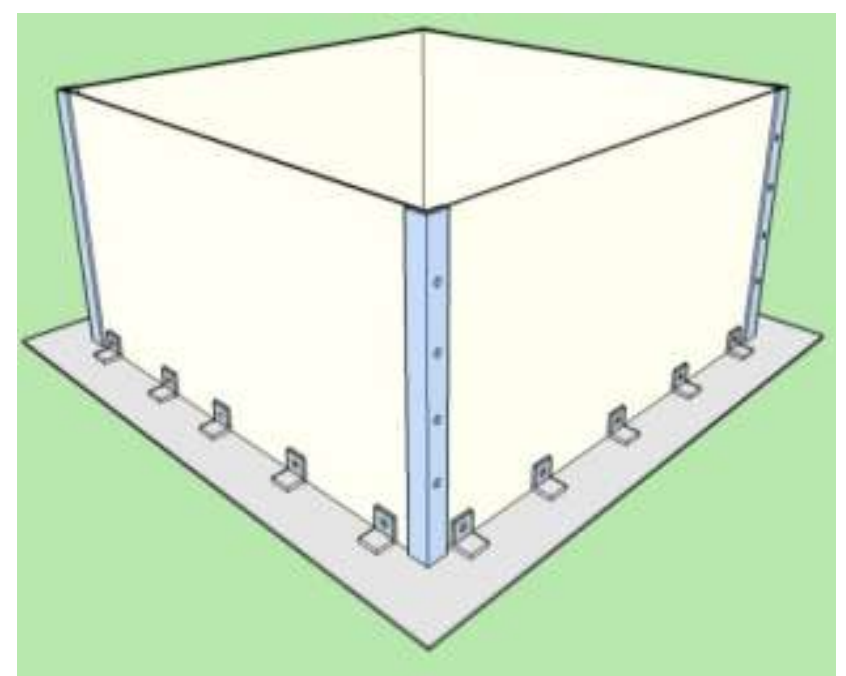

Fig -3: Isometric View of Steel Tank

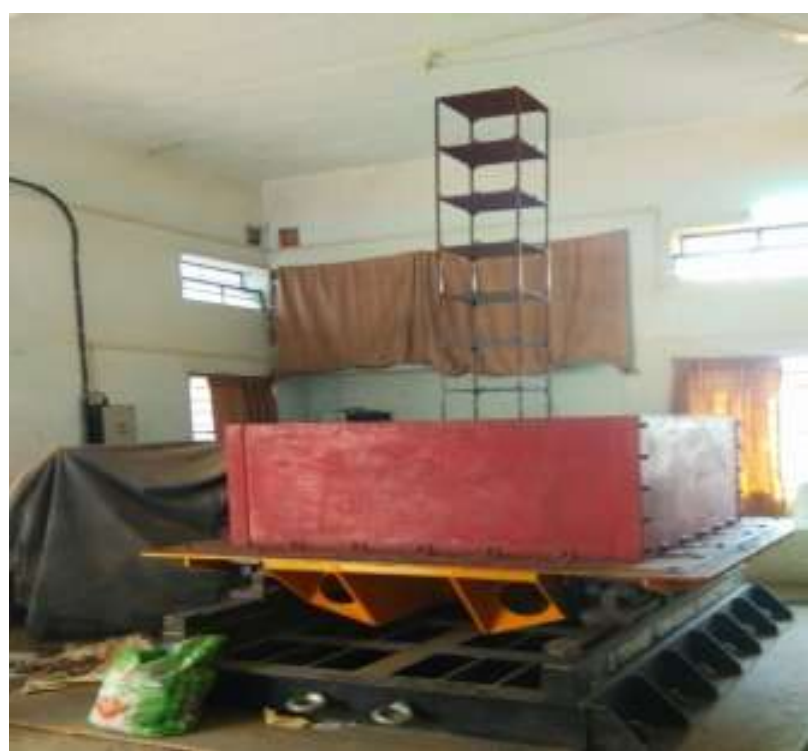

Fig- 4: Setup of Flexible Base 


\section{SOIL USED FOR STUDY}

Locally available soft soil is use for the study. Various index properties, strength properties and elastic constant of soil are determined in the laboratory as per the codal procedure.

Table -3: Properties of Soil

\begin{tabular}{|c|c|c|}
\hline $\begin{array}{l}\text { Sr. } \\
\text { No. }\end{array}$ & Name of Test & Results \\
\hline 1 & Specific Gravity & 2.806 \\
\hline \multirow[t]{3}{*}{2} & Compaction Properties & \\
\hline & Maximum dry density $\left(\mathrm{KN} / \mathrm{m}^{3}\right)$ & 19.2 \\
\hline & Optimum Moisture Content (\%) & $14 \%$ \\
\hline \multirow[t]{3}{*}{3} & Strength Parameters & \\
\hline & $\begin{array}{l}\text { Soil Internal Frictional Angle }(\varnothing) \text { in } \\
\text { degrees }\end{array}$ & 21 \\
\hline & Cohesion ' $\mathrm{C}$ ' $\left(\mathrm{KN} / \mathrm{m}^{2}\right)$ & 12 \\
\hline \multirow[t]{4}{*}{4} & Atterberg's Consistency Limits & \\
\hline & Liquid Limit (\%) & $40 \%$ \\
\hline & Plastic Limit (\%) & 28.26 \\
\hline & Shrinkage Limit (\%) & 22.115 \\
\hline \multirow[t]{3}{*}{5} & Particle Size Distribution Analysis & \\
\hline & $\%$ of sand & $29 \%$ \\
\hline & $\%$ of gravel & $71 \%$ \\
\hline 6 & Unit weight $\left(\mathrm{KN} / \mathrm{m}^{3}\right)$ & 16 \\
\hline 7 & Classification of Soil & $\begin{array}{l}\text { GW(Well- } \\
\text { graded } \\
\text { gravel })\end{array}$ \\
\hline 8 & Modulus of elasticity ' $\mathrm{E}$ ' $\left(\mathrm{KN} / \mathrm{m}^{2}\right)$ & 50000 \\
\hline 9 & Poisson's Ratio ' $\mu$ ' & 0.3 \\
\hline
\end{tabular}

\section{INPUT DATA TO SHAKE TABLE EL-} CENTRO TIME HISTORY

To know the performance of building, it is practiced to use time history of various earthquakes. The time history used for experimental study is Imperial Valley, California, $19^{\text {th }}$ May 1940 04:36 UTC (local 05/18), which has Magnitude 7.1

\section{5 .RESULTS AND DISCUSSION}

\subsection{Comparison of Fixed Base and Flexible Base}

\section{Condition}

In present work, a comparison is made between building frames resting on fixed base and flexible base to understand the effects of SSI. The structures are analyzed to study the dynamic parameters such as acceleration, velocity and displacement. Time history plots of $\mathrm{G}+3$ building for fixed and flexible base condition are shown below. The plots are responses at roof level. In the same way all buildings are analyzed and responses are taken at different stories.

\subsubsection{Plots for Fixed Base Condition}

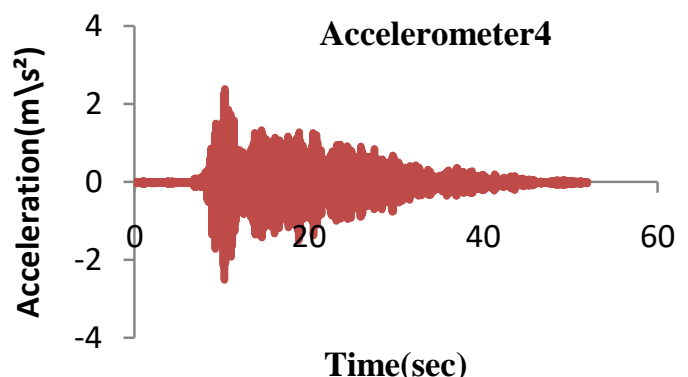

Chart-1: Acceleration Vs Time (fixed base)

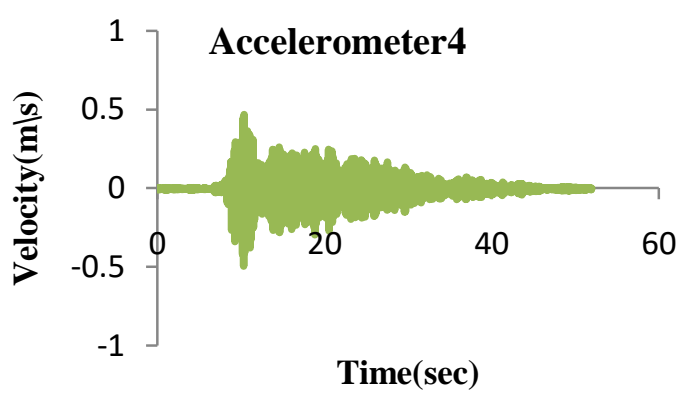

Chart-2: Velocity Vs Time (fixed base)

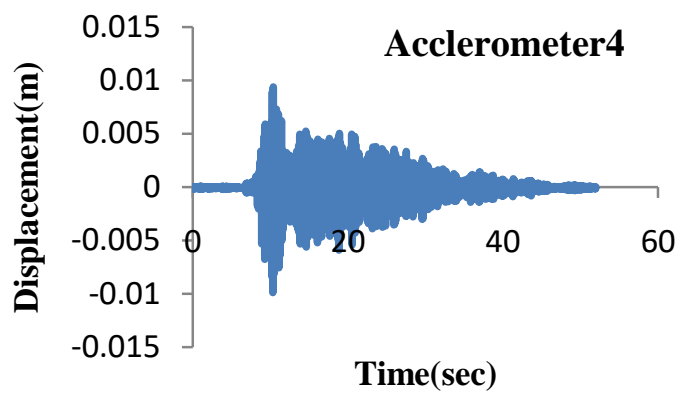

Chart-3: Displacement Vs Time (fixed base)

\subsubsection{Plots for Flexible Base Condition}

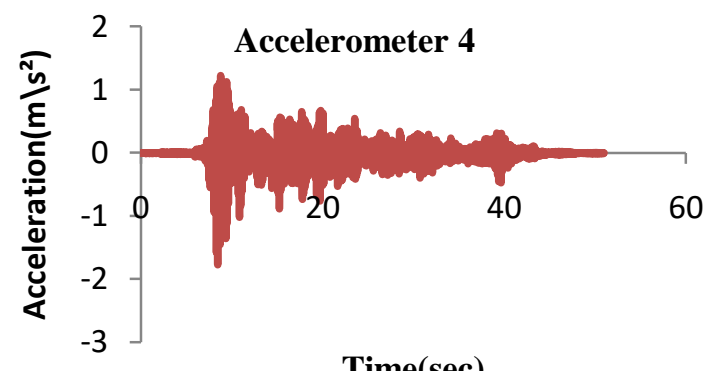

Time(sec)

Chart-4: Acceleration Vs Time (flexible base) 


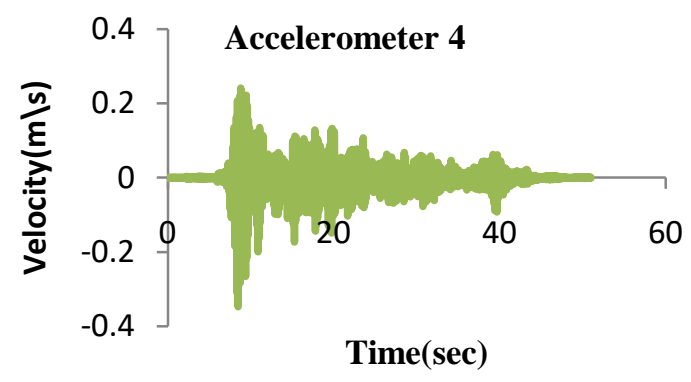

Chart-5: Velocity Vs Time (flexible base)

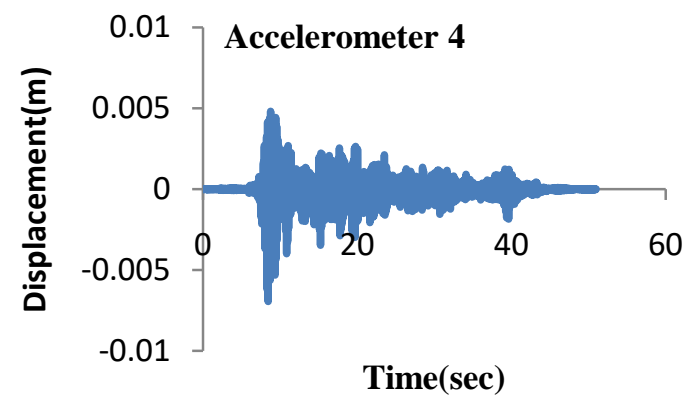

Chart-6: Displacement Vs Time (flexible base)

The results are discussed to highlight the effect of acceleration on fixed and flexible base. The results are presented for $\mathrm{G}+3, \mathrm{G}+5 \& \mathrm{G}+7$ building frames. Those are discussed below.

\subsection{Comparison of G+3 Building Frame}

\subsubsection{Comparison between Maximum Acceleration}

Velocity \& Displacement of Fixed \& Flexible Base

\section{Condition}

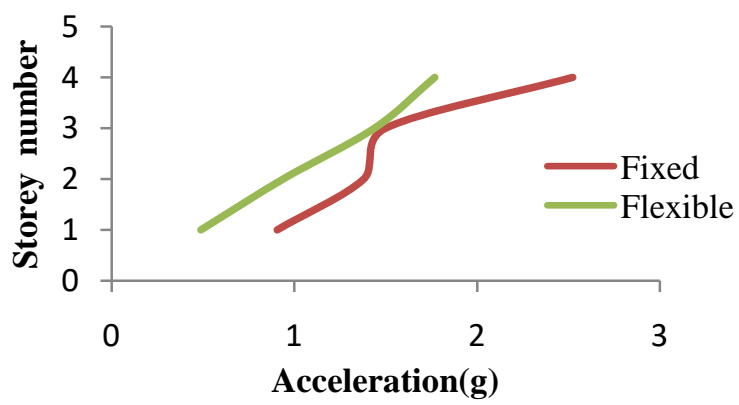

Chart-7: Variation of Maximum Acceleration (G+3)

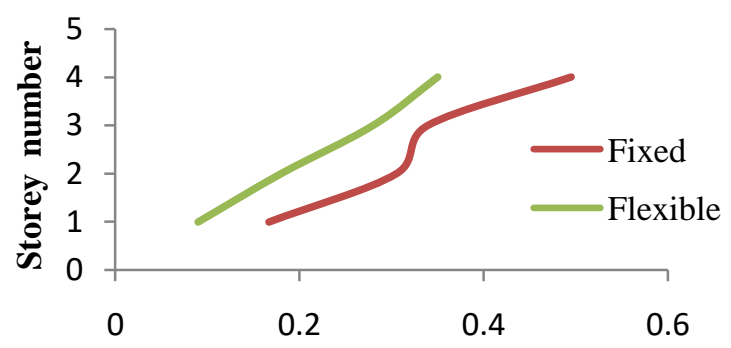

Velocity $(\mathrm{m} / \mathbf{s})$

Chart-8: Variation of Maximum Velocity $(\mathrm{G}+3)$

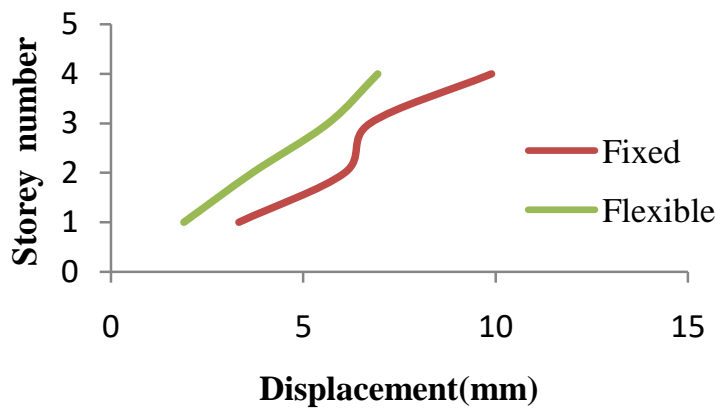

Chart-9: Variation of Maximum Displacement (G+3)

\subsection{Comparison of G+5 Building Frame}

5.3.1 Comparison between Maximum Acceleration Velocity \& Displacement of Fixed \& Flexible Base Condition

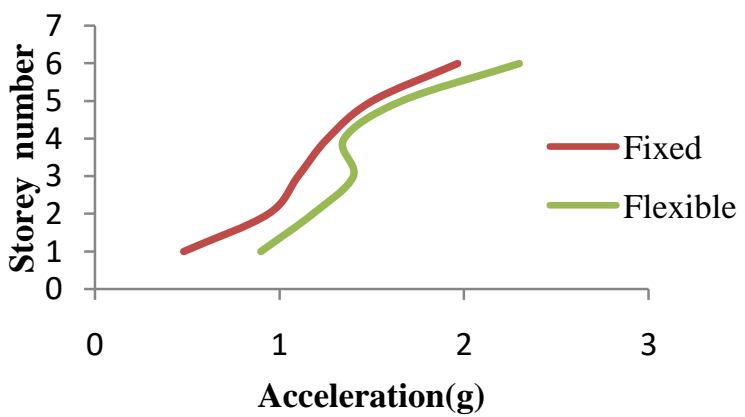

Chart-10: Variation of Maximum Acceleration $(\mathrm{G}+5)$ 


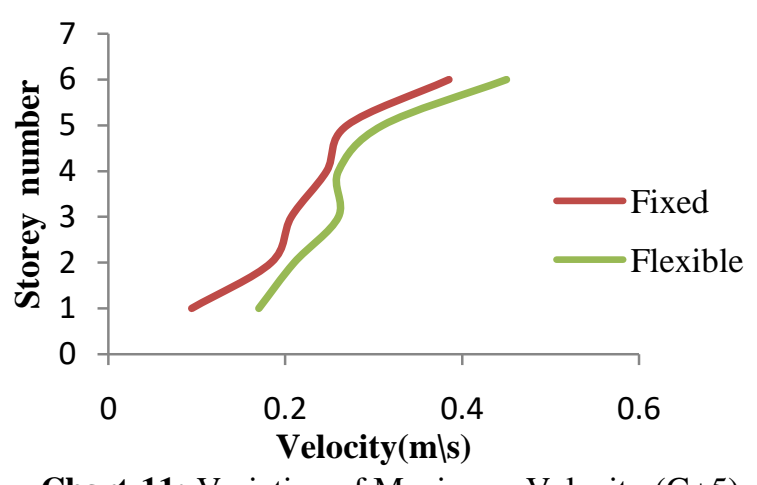

Chart-11: Variation of Maximum Velocity $(\mathrm{G}+5)$

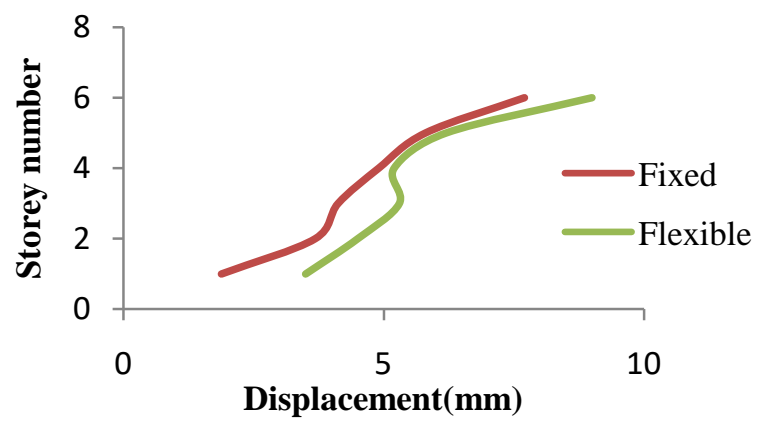

Chart-12: Variation of Maximum Displacement $(\mathrm{G}+5)$

\subsection{Comparison of G+7 Building Frame}

\subsubsection{Comparison between Maximum Acceleration}

\section{Velocity \& Displacement of Fixed \& Flexible Base}

\section{Condition}

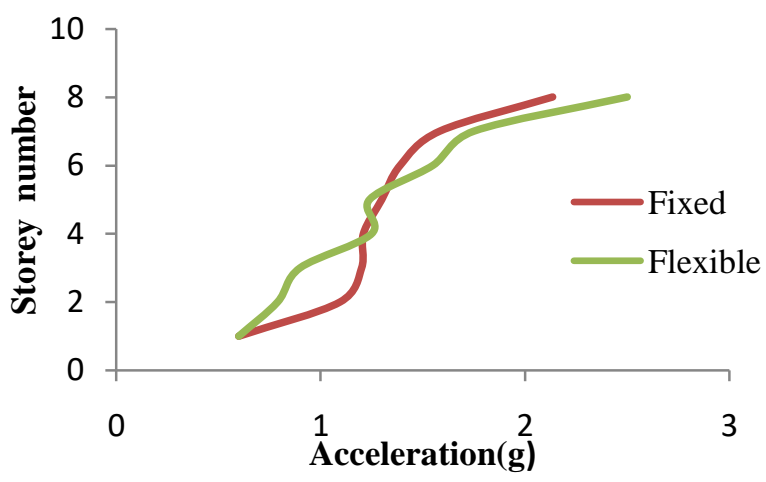

Chart-13: Variation of Maximum Acceleration $(\mathrm{G}+7)$

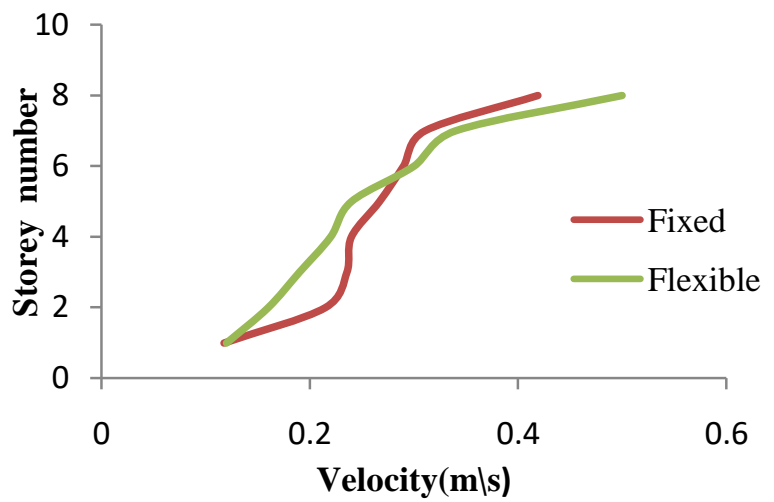

Chart-14: Variation of Maximum Velocity $(\mathrm{G}+7)$

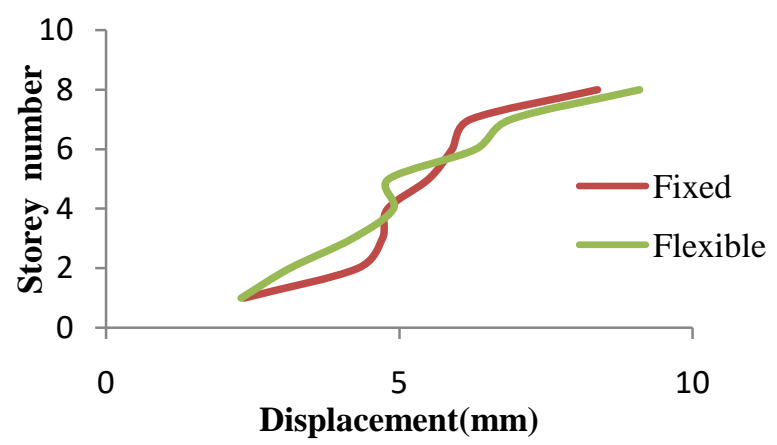

Chart-15: Variation of Maximum Displacement (G+7)

\section{CONCLUSION}

The test is conducted on el-Centro time history. The response of structure such as acceleration, velocity and displacement at all floor level of all building frame is determined for fixed and flexible base condition. The results obtained are presented in pervious chapter based on these observations following conclusions are drawn.

1. For all building frames it is observed that acceleration, velocity and displacement goes on increasing from ground level to roof level.

2. The rate of increase is observed relatively mild up to $3^{\text {rd }}$ storey (in case of $\mathrm{G}+5$ building), up to $5^{\text {th }}$ storey (G+7building) there onwards rate increases up to roof level.

3. In case of $\mathrm{G}+3$ building SSI effect is not significantly observed as the parameters for SSI are lesser than fixed base condition.

4. In case of $\mathrm{G}+5$ building SSI effect is significantly observed as response for SSI is higher than fixed base condition.

5. In case of $\mathrm{G}+7$ building SSI effect shows mixed kind of response. Up to $4^{\text {th }}$ storey SSI effect is not significant. Beyond this up to roof level SSI effect is significantly observed.

6. Study reveals that SSI effect is structure specific and input motion specific. For El-Centro time history and for given building configuration under consideration $\mathrm{G}+5$ building is severely affected than $\mathrm{G}+3$ and $\mathrm{G}+7$. 
7. Therefore during Earthquake depending upon frequency content of motion certain class of building are subjected to damage. The SSI effect plays important role in the performance of building frames.

8. The present study advocates that all the structures shall be analyzed considering SSI effect for specific site response spectra.

9. The SSI study is carried out on a GW type of soil. The results presented are for this soil only. In case of change in soil separate study shall be carried out.

\section{REFERENCES}

[1] George Gazetas (1991), Formulas and Charts for Impedances of Surface and Embedded Foundations, Journal of Geotechnical Engineering, Vol. 117, No. 9, September, 1991. CASCE, ISSN 07339410/91/0O09-1363.

[2] Sekhar Chandra Duttaa,, Koushik Bhattacharya, Rana Roy (2004), Response of low-rise buildings under seismic ground excitation incorporating soil-structure interaction, Soil Dynamics and Earthquake Engineering, 24, pp 893-914.

[3] M.H Rayhani,.and El Naggar, (2008), Numerical modeling of seismic response of rigid foundation on soft soil. International Journal of Geomechanics, 8(6), 336-346.

[4] P. Quintana-Gallo, S. Pampanin, \& A.J. Carr (2010), Shake table tests of under-designed RC frames for the seismic retrofit of buildings - design and similitude requirements of the benchmark specimen, 2010 NZSEE Conference.

[5] Akanshu Sharma, G.R. Reddy and K.K. Vaze (2012), Shake table tests on a non-seismically detailed RC frame structure, Structural Engineering and Mechanics, Vol. 41, No. 1 (2012) pp 1-24.

[6] Dhiraj Raj and M Bharathi (2013), Effects of SoilStructure Interaction on regular and Braced RC building.Proceedings of Indian Geotechnical Conference December 22-24, 2013, Roorkee.

[7] S. Hamid Reza Tabatabaiefar, BehzadFatahi and BijanSamali, Numerical and Experimental Investigations on Seismic Response of Building Frames under Influence of Soil-Structure Interaction.Advances in Structural Engineering,Volume 17 No. 12014.

[8] Umesh.R.Biradar and ShivarajMangalgi (2014), Seismic response of reinforced concrete structure by using different bracing systems. IJRET: International Journal of Research in Engineering and Technology eISSN: 2319-1163 pISSN: 2321-7308, Volume: 03 Issue: 09 Sep-2014.

[9] Dr. S. A. Halkude, Mr. M. G. Kalyanshetti, Mr. S. H. Kalyani(2014), Soil Structure Interaction Effect on Seismic Response of R.C. Frames with Isolated Footing. International Journal of Engineering Research \& Technology (IJERT), Vol. 3 Issue 1, January -2014.
[10] Krishnaraj R. ChavanandH.S.Jadhav(2014), Seismic Response of R C Building With Different Arrangement of Steel Bracing System. Int. Journal of Engineering Research and Applications ISSN : 22489622, Vol. 4, Issue 7( Version 3), July 2014, pp. 218 222.

[11] M. G. Kalyanshetti, S. A. Halkude, Y. C. Mhamane (2015), Seismic Response Of R.C. Building Frames With Strap Footing Considering Soil Structure Interaction. International Journal of Research in Engineering and Technology, eISSN: 2319-1163 pISSN: 2321-7308.

[12] G.M Sabnis, H.G Harris, R.N White and M.S Mirza (1983), Structural Modeling and Experimental Techniques, Prentice Hall Inc., Engelwood Cliff, New Jersey.

[13] IS 1893 (part 1): 2002, Indian Standard Criteria for Earthquake Resistant Design of Structures, Bureau of Indian Standards, New Delhi.

[14] IS 456:2000 Plain and Reinforced Concrete - Code of Practice, Bureau of Indian Standards, New Delhi.

[15] IS-2720 (Part 3):1980 "Methods of test for soil Determination of Specific Gravity "Bureau of Indian Standards, New Delhi.

[16] IS-2720(Part 7):1980, Methods of test for soils Determination of water content-dry density relation using light compaction. Bureau of Indian Standards, New Delhi.

[17] IS-2720 (Part 13):1986, Methods of test for soils Direct Shear Test. Bureau of Indian Standards, New Delhi.

[18] IS-2720 (Part 5):1985, Methods of test for soils Determination of Liquid and Plastic Limit. Bureau of Indian Standards, New Delhi.

[19] Bowles, Joseph E. (1996), Foundation Analysis and Design. Tata McGraw-Hill, New Delhi.

[20] Anil, K. Chopra. (2003), Dynamics of Structures, Theory and application to Earthquake Engineering., Prentice Hall, New Delhi.

[21] SAP 2000 Advanced 14.2.4, Computers and Structures Inc., University Avenue Berkeley, California, United State.

\section{BIOGRAPHIES}

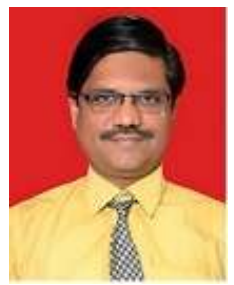

Dr. M. G. Kalyanshetti, PhD (Civil), M.E .(Civil - Structures), Associate Professor , PG Co-ordinator, Walchand Institute of technology,Solapur. Member of BOS Solapur University, Solapur , Institution of Engineers (India). Indian Society for Structural Engineer (ISSE).

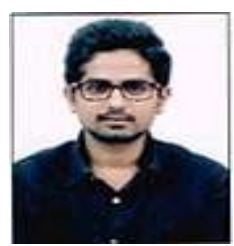

Mr. A. N. Wale, B.E.(Civil), M.E.(CivilStructures) 